\title{
Effect of Cow Parity and Calf Characteristics on Milk Production and Reproduction of Friesian Dairy Cows
}

\author{
Annah Indetie Hoka ${ }^{*} \quad$ Michael Gicheru ${ }^{2} \quad$ Syprine Otieno ${ }^{2}$ \\ 1.KALRO-National Beef Research Institute, P.O. Box 3840, Nakuru \\ 2.Kenyatta University, P.O Box: 43844-00100. Nairobi
}

\begin{abstract}
Viability and profitability of livestock enterprise is evaluated by the percentage of pregnant females over a period of time after exposure to bulls and amount of milk yield per lactation. This attribute was tested using 20 sevenmonth in calf Friesian dairy cows. Effect of parity on; gestation period, calf birth weight, milk production, lactation length, and postpartum heat were tested in this study. Effect of calf sex and calf birth weight on milk production and postpartum heat of the dam was also studied. Parity highly influenced gestation period with Cows at parity 4 taking significantly the least number of days (269.5 days). The cows at parity 4 delivered calves that recorded the highest calf birth weight mean $(39.0 \mathrm{~kg})$. Milk production per day was significantly higher in the cows at parity 4 $(17.0 \mathrm{~L})$. There was significant positive correlation $\left(\mathrm{r}^{2}=0.86, \mathrm{P}<0.001\right)$ between milk production and time to taken to exhibit postpartum heat Calf birth weight highly influenced milk production with dams of heavier calves producing significantly more milk than dams of lighter calves. Dams of heavier calves had significantly delayed postpartum heat. Calf sex significantly influenced milk production and postpartum heat. There was significant $\left(\mathrm{r}^{2}=0.79, \mathrm{P}<0.001\right)$ positive correlation between calf birth weight and time to postpartum heat. Adoption and use of these findings will improve dairy industry through reducing calving intervals. Calf Birth weight should be used as important traits in performance testing of dairy cattle.
\end{abstract}

Keywords: parity, Friesian cow, milk production

DOI: $10.7176 /$ JNSR/9-10-06

Publication date:May $31^{\text {st }} 2019$

\section{Introduction}

In Kenya, dairy industry is the single largest agricultural sub-sector than tea (Muriuki et al., 2004). It contributes 14 percent of agricultural GDP and 3.5 percent of the total GDP (Government of Kenya, 2008). The industry has tremendously grown since its liberalization in 1992 which increased informal milk trade that mainly consists of small-scale operators dealing in collection of raw milk, processing and marketing (KDB, 2009). Current milk consumption is 145 litres per person per year more than five times milk consumption in other East African countries (SDP, 2005) The consumption is bound to go up due to increased urbanization and wages (Government of Kenya, 2006). If production has to keep pace with demand then all factors that affect production must be identified and addressed.

Reproductive performance of dairy cows is affected by many factors including birth season, mangemental factors as well as the sex of birth calve. The postpartum period constitutes an important period that affects dairy cows' fecundity (Elmetwally et al., 2004). It is well known that the birth season has an effect on ovarian resumption (Crowe, et al., 2014), days open (Hammoud et al., 2010), milk yield as well as number of services per conception (Mham; et al: 2010). The onset of normal ovarian cyclic activity is one of the most important events for dairy cow to regain her maximum breeding potential following parturition. To attain a recommended calving interval of 12 months (Dijkhuizen et al., 1994)), cows should conceive within 85 days after parturition. This requires normal cyclicity within few weeks after calving. The interval in several herds could be reduced by breeding cows on first heat after 45 days postpartum and/or next to first examining the cows for normal reproductive tracts. Hamdi et al., (2012) reported many factors that caused prolonged days open in dairy cows (i.e. feeding season and milk production, silent estrus, frequency and timing of estrus detection, missed estrus due to weak symptoms). The objective of this study was therefore to determine the influence of parity, calf birth weight, and calf sex on dairy cow milk yield and on time taken to exhibit postpartum heat.

\section{MATERIALS AND METHODS}

Study site

KALRO -Lanet ( $0^{\circ} 27^{\prime} 09^{\prime} \mathrm{S}$ and $39038^{\prime} 45^{\prime} \mathrm{E}$ (Oliveira, 2018), is located in Nakuru County, Kenya at an elevation of 1600 meters above sea level. The area has a bimodal rainfall pattern with an annual mean rainfall of $800 \mathrm{~mm}$ ranging from 534 to $1,049 \mathrm{~mm}$ and $83 \%$ relative humidity. Temperature ranges between 8 to $20^{\circ} \mathrm{C}$ (Pratt and Gwyne, 1977). Soils are deep sandy loam with good water holding capacity with pH range of 5.5 to 6.5 (Mwangi et al., 2017). 


\section{Experimental animals}

Twenty ranched Friesian dairy cows were randomly selected using a table of r6andom digits and were enrolled in this study. Criteria for selection included Friesian cow that were seven months in-calf. The cows were grazed for 8 hours on established pastures of. Elmba Rhodes grass leys interspersed with natural Themeda Triandra and star grass (Cynodon Dactaylon). The cows were supplemented at milking with $2 \mathrm{~kg}$ of Total mixed ration of Brachiaria ruziziensis mutant line K600 and Dolichos lablab mutant line D600 leaves and conserved in multi-nutrient feed block form. Details of milk produced, parity, gestation period, sex of calf, calf birth weights, time to postpartum heat, and lactation period were recorded.

Five milliliters of milk was collected thrice a month from each cow by aseptically stripping $10 \mathrm{mls}$ of evening milk into sterile milk container and one tablet of sodium azide was added to the milk as preservative and the container was sealed. The milk was stored at $4^{\circ} \mathrm{C}$ until assaying. The milk was analyzed for presence of progesterone using radioimmunoassay technique; self-coating procedure (FAO/IAEA, 1999).

\section{Preparation of multi-nutrient block}

If the feed block is too hard it may not be consumed at all (Kunju, 1986). A binder is necessary in order to solidify the blocks, bentonite clay has many advantages over other binders. Bentonite is one of the common natural clays used in animal diets to improve digestibility of nutrients and daily gain and feed intake (Salem et al., 2001). Bentonite can absorb toxic products of digestion and decrease the accumulation of toxic substances in tissues, thus decreasing the incidence of internal disorders (Khadem et al., 2007). The addition of bentonite to the diet can partly equalize the supply of nitrogen to the rumen microorganisms.

Bales of Brachiaria grass were half ground whereas Dolichos lablab leaves were completely ground using a grinder (hammer mill). The ingredients used for making multi-nutrients feed blocks were ground Brachiaria, and Dolichos lablab leaves, lemon rind, common salt, mineral premix, cement, bentonite and molasses binder (Table.1). Water was taken at the rate of one third of binder in a plastic basin of about 10 litres capacity. To this salt, lemon rind, mineral premix, was thoroughly mixed then the ground feed was added. After this, binder was gradually poured in the same basin. The whole mass was thoroughly stirred with the help of a wooden rod by adding gradual amount of molasses in the plastic basin. After that whole mixed feed was transferred into sets of open ended molds placed on flat even ground and gently pressed using filled 2 litre water plastic bottles. Well compacted the feed blocks were gently removed from the molds by lifting the molds up and leaving the blocks on polythene paper. The resultant feed blocks were left in a well aerated place for 3 days to cure then transferred to a greenhouse where they were placed on grills for 3 days to dry. The dry feed blocks were kept in a well aerated raised dry ground for complete drying and long storage. All the dried blocks were poly-packed and thereafter keeping quality of blocks was assessed using ELISA technique.

Table1. Physical composition of solid multi-nutrients block

\begin{tabular}{ll}
\hline Ingredient & Amount (\%) \\
\hline Ground Brachiaria & 55 \\
Round Dolichos leaves & 15 \\
Common Salt & 1 \\
Bentonite Clay & 5 \\
Lemon Rinds & 8 \\
Mineral Premix (Unga ltd) & 1 \\
Portland Cement & 5 \\
Molasses & 10 \\
\hline
\end{tabular}

\section{Determining Feed Nutritional Composition}

The pastures were sampled monthly from the grazing fields. This was done by randomly throwing a $1 \mathrm{~m}^{2}$ quadrant diagonally across the field and the swath within the quadrant was cut using a sickle. After mixing the various quadrant swaths, a sub sample from the mixture was picked in duplicate then prepared for laboratory analysis. The forage and feed block samples were oven dried at $106^{\circ} \mathrm{C}$ for 12 hours after which DM, NDF, ADF, ADL and CP were determined using the Van Soest method (AOAC, 1995). The muffle furnace was used to determine the ash content of the established forage and feed blocks fed to the experimental cows.

\section{Statistical analysis}

Data collected were subjected to Analysis of variance (ANOVA) and treatment means were separated using Duncan multiple range test at $\alpha=0.05$. Descriptive statistics was done using the Proc Univariate procedure in SAS. Statistics analysis software (SAS) Version 9.3 was used for the analysis (SAS 2010). 


\section{RESULTS AND DICUSSIONS}

Feed Analyses

The nutritive values of forage and feed blocks fed to experimental cows are summarized in Table 2. These values are higher than those obtained in the East African region as reported by Smith et al. (2006) in Ethiopia and Irungu and Mbugua (1998) in Kenya. They reported a mean crude protein of $15.8 \%$ and $8.3 \%$, while crude fibre was $9.6 \%$ and $32.3 \%$ for dairy meal and pasture respectively. High values for NDF as indicated below reflect the good pastures used, and were suitable in enhancing rumen function (Russel et al. 1992). The aflatoxin level was 7.4 ppm after 9 months of keeping. This level were below the threshold of $10 \mathrm{ppm}$ and therefore safe to be used as animal feed (FAO, 2004)

Table 2: Mean \pm SD of Nutritional Values of Forage and Concentrate Fed to Cows

\begin{tabular}{lll}
\hline Nutritional Component: & Forage (\%) & Feed block (\%) \\
\hline Dry Matter & $36.8 \pm 2.5$ & $86 \pm 3.7$ \\
Crude Protein & $4.7 \pm 2.2$ & $26 \pm 1.1$ \\
Neutral Detergent Fiber & $41.7 \pm 6.7$ & $72.7 \pm 9.5$ \\
Acid Detergent Fiber & $42.6 \pm 2.5$ & $38.4 \pm 4.9$ \\
Acid Detergent Lignin & $4.7 \pm 1.6$ & $4.1 \pm 0.6$ \\
Ash & $8.9 \pm 1.3$ & $20 \pm 2.1$ \\
Total aflatoxin (ppm) & - & $7.4020 \pm 0.3$ \\
\hline
\end{tabular}

\section{Effect of cow and calf characteristics on the cow performance}

The analysis of variance (ANOVA) indicated that parity, and calf sex had an effect on the cow performance. Parity had a significant $(\mathrm{P}<0.05)$ effect on gestation period. There was no significant $(\mathrm{P}>0.05)$ parity effect on the calf birth weight, lactation period and months to heat after calving (Table 3). The sex of the calf had a significant effect on the calf weight, milk production and months to next heat (Table 3 ).

Table 3: ANOVA mean square values for the factors affecting the cow performance

\begin{tabular}{|c|c|c|c|c|c|c|}
\hline $\begin{array}{l}\text { Source } \\
\text { variation }\end{array}$ & of & $\begin{array}{l}\text { Calf birth } \\
\text { weight }\end{array}$ & $\begin{array}{l}\text { Milk } \\
\text { production }\end{array}$ & $\begin{array}{l}\text { Lactation } \\
\text { period }\end{array}$ & $\begin{array}{ll}\text { Months } & \text { to } \\
\text { next heat }\end{array}$ & $\begin{array}{l}\text { Gestation } \\
\text { period }\end{array}$ \\
\hline Parity & 3 & $49.9^{\text {ns }}$ & $18.8^{* *}$ & $1.3^{\mathrm{ns}}$ & $0.46^{\mathrm{ns}}$ & $7.1^{* *}$ \\
\hline Calf sex & 1 & $434.1^{* *}$ & $31.5^{* * *}$ & $1.4^{\mathrm{ns}}$ & $2.94^{*}$ & $0.5^{\mathrm{ns}}$ \\
\hline Error & 5 & 26.3 & 0.6 & 5.0 & 0.21 & 0.4 \\
\hline Total & 19 & & & & & \\
\hline
\end{tabular}

\section{Effect of parity on cow performance}

Effect on gestation period

Cows at parity 4 took significantly the least number of days (269.5 days) followed by parity 3 . No significant difference was observed in the gestation period between parity 1 and 2 (Table 2). There was significant $(\mathrm{P}<0.05)$ difference in gestation period with gestation period reducing with increased parities (Table 2). This finding was similar with the finding of Nogalski et al. (2012) who reported optimal gestation length in the range of (275-277) days based on calving ease and stillbirth values for parities 1 and 2 but the gestation period of parities 3 and 4 differed with his findings. This could be due to non-still birth cases reported in this study. Still birth cases increase gestation length (Nogalski et al., 2012).

\section{Effect on calf weight}

The cows at parity 4 delivered calves that recorded the highest calf weight mean $(39.0 \mathrm{~kg})$ while the cow at parity 2 recorded the least calf weight $(29.2 \mathrm{~kg})$. However, these differences in calf weights were not statistically significant from each other among the four parities (Table 2). It was expected that calf birth weights increase with increased parity due to less competitive demand on nutrients between calf and dam. This finding differed with the results of Adeneye et al. (1977) that Friesian dams with three or more parities and Holstein dams that were 3 years old and above produced calves that were significantly $(\mathrm{P}<0.01)$ heavier at birth than calves of younger dams.

\section{Effect of parity on milk production}

The milk production per day was significantly higher in the cows at parity $4(17.0 \mathrm{~L})$ that was significantly different from the parities 1-3 (Table 2). This finding agreed with the finding of Koc (2011) who reported increased trend in milk yield up to third parity in Friesian crosses. This also agreed with the finding of Ríos-Utrera et al. (2013) who reported that Milk yield traits and cow weight showed a significant increasing trend from first to fourth lactation. This was expected since the udder is physiologically fully developed in higher parity cows than in lower parity cows. Competition on feed for growth is lower in higher parity cows than lower parity cows this is coupled with greater feed intake in older cows than young ones (Johnson et al., 2002) hence the difference in the amount 
of milk produced. Cows at parity 4 could have contributed to increased milk production through higher numbers of newly produced active secretory cells. Afzal et al. (2007) reported that milk production was significantly lower in the first lactation than the yield in the $2^{\text {nd }}, 3^{\text {rd }}$ and $4^{\text {th }}$ lactation $(\mathrm{p}<0.05)$. However, the yield of first lactation was not different from that of $5^{\text {th }}, 6^{\text {th }}$ and $7^{\text {th }}$ lactation.

\section{Effect on lactation length}

Cows at parity 2 and 4 took slightly longer period in milk as compared to parity 1 and 3 . There was no significant difference in lactation length among the parities considered. This non-significant difference in lactation length among different parities agreed with finding from previous studies (Koc, 2011; Usman et al., 2012; Zewdu et al., 2013) who reported insignificant effect of parity on lactation length but differed with the finding of Licitra et al. (1990) who reported significant effect of parity on lactation length. Calf sex did not influence lactation length, this finding agreed with the results of Afzal et al. (2007) who reported that lactation length was not affected by calf sex. It was expected that dams with bull calves which produced more milk would have an extended lactation length compared to dams of heifer calves. The results of this study could be due to limited parities available for the study.

\section{Effect of parity on postpartum heat}

The cows at parity 4 took the longest time (4.1 months) to show heat after calving, though not significantly different from the other parity levels (Table 4). This disagreed with the finding of Mohammed et al. (2016) who reported longer days open (177.65 \pm 69.22$)$ in multiparous Friesian dairy Cow after first parturition and shorter $(95.66 \pm$ 35.97 ) after the $6^{\text {th }}$ parity. It agreed with the finding of Folnožić et al, (2016) who concluded that primiparous cows are more susceptible to metabolic stress during the transition period, and that their metabolic and endocrine profiles are more unbalanced as compared to the multiparous cows, which results in more severe and prolonged recovery from negative energy balance. This could explain the non-significant difference obtained between parities in this study since the study did not enroll cows at parity 6 . However the finding

\section{Table 4: Effect of parity on cow performance}

\begin{tabular}{|c|c|c|c|c|c|c|c|c|}
\hline Parity & $\begin{array}{l}\text { Calf } \\
(\mathrm{kg})\end{array}$ & weight & $\begin{array}{l}\text { Milk production } \\
(\mathrm{kg})\end{array}$ & $\begin{array}{l}\text { Lactation } \\
\text { (months) }\end{array}$ & period & $\begin{array}{l}\text { Months to next } \\
\text { heat }\end{array}$ & $\begin{array}{l}\text { Gestation } \\
\text { (days) }\end{array}$ & period \\
\hline 1 & $31.0^{\mathrm{a}}$ & & $11.3^{\mathrm{b}}$ & $10.5^{\mathrm{a}}$ & & $3.2^{\mathrm{a}}$ & $273.4^{\mathrm{a}}$ & \\
\hline 2 & $29.2^{\mathrm{a}}$ & & $11.7^{\mathrm{b}}$ & $11.0^{\mathrm{a}}$ & & $3.4^{\mathrm{a}}$ & $273.0^{\mathrm{a}}$ & \\
\hline 3 & $30.0^{\mathrm{a}}$ & & $11.3^{b}$ & $9.5^{\mathrm{a}}$ & & $3.2^{\mathrm{a}}$ & $271.0^{\mathrm{b}}$ & \\
\hline 4 & $39.0^{\mathrm{a}}$ & & $17.0^{\mathrm{a}}$ & $11.0^{\mathrm{a}}$ & & $4.1^{\mathrm{a}}$ & $269.5^{\mathrm{c}}$ & \\
\hline
\end{tabular}

Means followed by the same superscript letter within a column are not significantly different from each other at $\alpha$ $=0.05$.

\section{Effect of calf sex on cow performance}

Significantly higher calf weights were observed in the male calves $(37.1 \mathrm{~kg})$ as compared to the female calves $(25.2 \mathrm{~kg})$. The cows that gave birth to male calves produced significantly higher amount of milk than those with female calves (Table 5). This finding agreed with the finding of Hinde et al. (2014) who reported that U.S. Holstein dams that gave birth to daughters had higher milk yields than dams that gave birth to sons, and that first parity calf gender affected milk yield in subsequent lactations. The finding of this study differed with the results of Afzal et al. (2007) who reported buffaloes with heifer calves gave more milk than buffaloes with male calves.

The months to next postpartum heat were significantly $(\mathrm{P}<0.05)$ higher for cows with male calves than those with female calves. This could be due to larger body size of male calf leading to longer time to clear postpartum fluids from the uterus or presence of the $\mathrm{Y}$ antigens in the male fetus and a local immune reaction towards the fetal testosterone.

The lactation period was statistically similar for cows with male and female calves (Table 5). This finding agreed with results of Afzal et al. (2007) who reported no significant difference in lactation length of buffaloes with male and female calves.

Table 5: The effect of calf sex on cow performance

\begin{tabular}{llllll}
\hline Calf sex & Calf weight & $\begin{array}{l}\text { Milk production } \\
\text { (daily) }\end{array}$ & $\begin{array}{l}\text { Lactation } \\
\text { period (months) }\end{array}$ & $\begin{array}{l}\text { Months to next } \\
\text { heat }\end{array}$ & Gestation period \\
\hline Male & $37.1 \pm 1.3$ & $14.3 \pm 0.21$ & $11.0 \pm 0.53$ & $3.9 \pm 0.03$ & $271.9 \pm 0.48$ \\
Female & $25.2 \pm 1.5$ & $9.7 \pm 0.59$ & $10.2 \pm 0.73$ & $2.7 \pm 0.12$ & $271.3 \pm 0.26$ \\
\hline
\end{tabular}

Values are means of the calf sex \pm the standard error of the means

There was a significant $\left(\mathrm{r}^{2}=0.73, \mathrm{P} \leq 0.001\right)$ positive correlation between the calf weight and milk production (Table 6). This finding agreed with the results of Rahba et al. (2016) who reported that birth weight is a significant parameter in cow milk production trait. Therefore, birth weight could be considered as an important trait in dairy cattle breeding programs.

There was significant $\left(\mathrm{r}^{2}=0.79, \mathrm{P} \leq 0.001\right)$ positive correlation between calf birth weight and postpartum heat 
(Table4) with postpartum cows having heavier calves taking longer period to show heat than dams with lighter calves. This was expected due to longer time taken for uterine involution by dams with heavier calves. This differed with the finding of Guedon et al. (1999) who reported that calf birth weight was not related to time of first ovulation. The difference could be due to different breeds used, he used beef cows and the present study used Friesian cows.

There was a significant $\left(\mathrm{r}^{2}=0.86, \mathrm{p} \leq 0.001\right)$ positive correlation between the milk production and the months to next heat signs. This was expected due to energy partitioning which favours milk production in early lactation. During early part of lactation, dry matter intake remains suboptimum thus dairy cow is unable to meet production requirements though intake, hence the little energy she gets through converting her body fats to energy is prioritized for milk production for her calf, the extra is converted to heat exhibition later hence the delay in postpartum heat exhibition. There was non-significant correlation of the factors considered with lactation period and gestation period (Table 6).

Table 6: Correlation of the cow performance indicators

\begin{tabular}{llllll}
\hline & $\begin{array}{l}\text { Calf } \\
\text { weight }\end{array}$ & $\begin{array}{l}\text { Milk } \\
\text { production }\end{array}$ & $\begin{array}{l}\text { Lactation } \\
\text { period }\end{array}$ & $\begin{array}{l}\text { Months to next } \\
\text { heat }\end{array}$ & $\begin{array}{l}\text { Gestation } \\
\text { period }\end{array}$ \\
\hline Calf weight & 1 & $0.73^{* * *}$ & $0.21^{\mathrm{ns}}$ & $0.79^{* * *}$ & $-0.15^{\mathrm{ns}}$ \\
Milk production & & 1 & $0.35^{\mathrm{ns}}$ & $0.86^{* * *}$ & $-0.34^{\mathrm{ns}}$ \\
Lactation period & & & 1 & $0.41^{\mathrm{ns}}$ & $0.13^{\mathrm{ns}}$ \\
$\begin{array}{l}\text { Months to next heat } \\
\text { Gestation period }\end{array}$ & & & & 1 & $-0.13^{\mathrm{ns}}$ \\
\hline
\end{tabular}

***- significant at $\mathrm{p} \leq 0.001, \mathrm{~ns}-$ not significant

\section{Conclusion}

The cow parity affected the gestation period, daily milk production, but did not affect; calf birth weight, neither lactation length nor time to postpartum heat. The calf sex affected the calf birth weight, time to postpartum heat, and daily milk production, but did not affect the lactation length, time to postpartum heat, gestation period. There was significant positive correlation between milk production and time to postpartum heat. There was significant positive correlation between calf weight and postpartum heat. We therefore recommend that parity and calf birth weight should be used as important traits in performance of dairy cattle. Further work should include designing experiment to validate the importance of calf birth weight in dairy cattle breeding programs since we found a high correlation between birth weight and milk production.

\section{References}

Adeneye, J., Bamiduro, T., Adenbanjo, A. and Akinyemi, A. (1977). Factors affecting birth weight of HolsteinFriesian calves in Western Nigeria. J Agr Sci 88(1): 111-117.

Afzal, M., Anwar M. and Mirza, M. A. (2007). Some Factors Affecting Milk Yield And Lactation Length In Nili Ravi Buffaloes. Pakistan Vet J 27(3): 113-117.

AOAC (1995). Official methods of Analysis (16 ${ }^{\text {th }}$ Edition).Association of Official Analytical Chemists, Washington, D.C.USA. pp36.

Crowe, M.A., Diskin, M.G. and Williams, E.J. (2014). Parturition to resumption of ovarian cyclicity: comparative aspects of beef and dairy cows. Animal 1 (8): 40-53.

Dijkhuizen, T.J. and van Eerdenburg, F.J.C.M. (1997). Behavioural signs of oestrus during pregnancy in lactating dairy cows. Vet Quart 119: 194-6.

Elmetwally, M. A. (2004). Postpartum ovarian rebound, Master thesis, Mansoura University, Faculty of veterinary medicine.

FAO 2004. Worldwide regulations for mycotoxins in food and feed in 2003. Available at:

Folnožić, I., Turk, R., Đuričić, D., Vince, S., Flegar-Meštrić, Z., Sobiech, P., Lojkić, M., Valpotić, H. and Samardžija, M. (2016). The effect of parity on metabolic profile and resumption of ovarian cyclicity in dairy cows. Veterinarski arhiv $86(5), 641-653,2016$

Government of Kenya (2006). Sessional paper on dairy industry development

Government of Kenya (2008). Sessional paper on National Livestock Policy.

Guedon, L., Saumande, J. and Desbals, B. (1999). Relationships between calf birth weight, prepartum concentrations of plasma energy metabolites and resumption of ovulation postpartum in limousine suckled beef cows. Theriogenology. 52(5): 779-789.

Hamdi, M., Mahdi, N., Frouja, B., Ressaissi, S., Brar, Y. and Hamouda, M.B. (2012). Effects of environmental factors on milk yield, lactation length and dry period in Tunisian Holstein cows. In Tech.http://dx.doi.org/10.5772/50803. [Accessed $1^{\text {st }}$ March 2019].

Hammoud, M.H., El-Zarkouny, S.Z., and Oudah, E. Z. M. (2010). Effect of sire, age at first calving, season and year of calving and parity on reproductive performance of Friesian cows under semiarid conditions in Egypt. 
Archiva Zootechnica 13(1): 60-82.

Hinde, K., Carpenter, A.J., Clay, J.S. and Bradford, B.J. (2014). Holsteins Favor Heifers, Not Bulls: Biased Milk Production Programmed during Pregnancy as a Function of Fetal Sex. Plos One 9(2):7.

http://www.fao.org/docrep/007/y5499e/y5499e07.htm [Accessed April 2, 2019].

Irungu, K. R. G. and Mbugua, P. N. (1998). Feeding dairy cows to increase performance on Rhodes grass ley. In: Proceedings of the $6^{\text {th }}$ biannual KARI conference. Agricultural Research and Development for Sustainable Resource Management and Increased Production. Agronam Services Ltd (Eds), Nairobi, Kenya. pp 608.

Johnson, C. R., Lalman, D.L ., Appeddu-Lisa, A., Brown-Michael, A., Wetteman, R.P. and Buchanan, D.S. (2002). Effect of parity and milk production potential on forage intake of beef cows during late gestation. TEKRAN United States Department of Agriculture, Agricultural Research Service.

Khadem, A.A., Soofizadeh, M. and Afzalzadeh, A. (2007). Productivity, Blood Metabolites and Carcass Characteristics of Fattening Zandi Lambs Fed Sodium Bentonite Supplemented Total Mixed Rations. Pak J Biol Sci 10: 3613-3619.

Koc, A. (2011). A study of the reproductive performance, milk yield, milk constituents, and somatic cell count of Holstein-Friesian and Montbeliarde cows. Turk J Vet Anim Sci 35(5):295-302.

Kunju, P. J. G. 1986. Urea molasses block: A future animal feed supplement. Asian Livestock 154-159.

Licitra, G., Oltenacu, P.A., Blake, R.W., Lanza, A. and D'Urso, G. (1990). Season of calving and parity effects on milk yield and reproduction of Modicana and Holstein cows in Sicily. J Dairy Sci 73: 224.

Mohammed, A., Montaser, A., Elsadany, N., Bedir, W., Hussein, M. and Zaabel, S. (2016). Effects of parity on postpartum fertility parameters in Holstein Dairy Cows. J Agric Vet Sci 9(8): 91-99.

Mwangi, P. G., Gachuiri, C.K. and Mbugua, P.N. (2017). Effect of growth stage on fodder yield and quality of dual purpose sorghum. Trop Drylands 1(2): 100-104.

Nogalski, Z. and Piwczuski, D. (2012). Association of Length of Pregnancy with Other Reproductive Traits in Dairy Cattle. Asian-Australas, J Anim Sci 25(1): 22-27.

Oliveria, R. C. (2018). Characterization of remarkable mutants and ecotypes of Brachiaria (Urochloa Spp.) and new collections of forage grasses in Kenya. Pro. Plant Mutation Breeding and Biotechnology. VIC Vienna, Austria, 189 (Abstr).

Pratt, D.J., and Gwynne, M.D. (1977). Rangeland management and ecology in East Africa. Hodder and Stoughton, London, England.

Rahbar, R., Abdullahpour, R. and Sadeghi-Sefidmazgi, A. (2016). Effect of calf birth weight on milk production of Holstein Dairy Cattle in Desert Climate. J Anim Behav Biometeorol 4 (3): 65-70.

Ríos-Utrera, A., Calderón-Robles., R.C., Galavíz-Rodríguez, J.R., Vega-Murillo, V.E. and Lagunes-Lagune, J. (2013). Effects of Breed, Calving Season and Parity on Milk Yield, Body Weight and Efficiency of Dairy Cows under Subtropical Conditions. Int J Anim Vet Adv 5(6): 226-232.

Russell, J.B., O’Connor. J.D., Fox, D.G., Van Soest, P.J. and Sniffen, C.J. (1992). A net carbohydrate and protein system for evaluating cattle diets. 1 Ruminal fermentation. J Anim Sci 70:3551-3561.

Salem, F.A.F., El-Amary, H. and Hassanin, S. H. (2001). Effect of bentonite supplementation on nutrients digestibility, rumen fermentation, some blood physiological parameters and performance of growing lambs. Egypt. J Nutr Feeds 4: 179-191

Smallholder dairy project. (2005). The uncertainty of cattle numbers in Kenya SDP Policy Brief No. 10 Smallholder Dairy (R\&D) Project. www.smallholderdairy.org

Smith, D. G., Cuddeford, D. and Pearson, R. (2006). The effect of extended grazing time and supplementary forage on the dry matter intake and foraging behavior of cattle kept under traditional African grazing systems. Trop Anim Health Prod 38: 75-84.

Usman, T., Guo, G., Suhail, S.M., Ahmed, S., Qiaoxiang, L., Qureshi, M.S. and Wang, Y. (2012). Performance traits study of Holstein Friesian cattle under subtropical conditions. J Anim Plant Sci 22(2):92-95.

Zewdu, W., Thombre, B.M. and Bainwad, D.V. (2013). Effect of non-genetic factors on milk production of Holstein Friesian Deoni crossbred cows. Int J Livest Prod 4(7):106-112. 